\title{
Comparative study of immunological tests for pregnancy diagnosis
}

\author{
JOYCE L. BELL
}

From the Department of Chemical Pathology, The Royal Free Hospital, London

SYNOPSIS The reliability of five commercially produced immunological pregnancy diagnosis methods has been investigated. The tests used were Pregnosticon (a tube test) and four slide tests, Hyland, Pregslide, Gravindex, and Planotest. In the series described, Planotest gave $0.5 \%$ false positives, Gravindex had 2.1\%, Pregnosticon 2.6\%, and Pregslide $4 \cdot 7 \%$, Hyland A (sensitivity 4,500 iu/l.) gave 3.6\% and Hyland B (sensitivity 2 to 3,000 iu/1.) had $8.7 \%$ false positives. Pregnosticon had $0.5 \%$ false negatives, Planotest $2.0 \%$, Gravindex $3.5 \%$, Hyland B $6.5 \%$, Pregslide $9 \%$, and Hyland A $19 \cdot 5 \%$ false negatives.

Planotest and Pregnosticon were found to be less influenced by protein and blood in the urine than the other pregnancy tests investigated.

Although many papers have been written on individual immunological pregnancy tests, such as the Gravindex slide test, ${ }^{1}$ and such tube tests as Pregnosticon, ${ }^{2}$ UCG, ${ }^{3}$ Prepuerin, ${ }^{4}$ and the Ortho test, ${ }^{1}$ there is a lack of papers comparing these tests with each other. In many papers also, clinical confirmation of the diagnosis was not obtained and the patients were not divided according to the state of the pregnancy. Recently, some new slide tests, which have advantages over the tube tests in simplicity and time taken to obtain a result, have been produced and these have not been adequately investigated. For these reasons it was thought that it would be of interest to compare all the available slide tests with one tube test, Pregnosticon, which had been in use in this laboratory for some years.

\section{METHODS}

Pregnancy tests were carried out on 686 early morning specimens of urine. Final diagnoses on all patients were obtained either from the case notes or by correspondence with the general practitioner. Four hundred and eightysix urines were tested with four different pregnancy

${ }^{1}$ Ortho Diagnostics, Raritan, New Jersey, USA (English address, Saunderton, Bucks.).

${ }^{2}$ N.V. Organon, Oss, Holland (English address, Organon Laboratories, Crown House, Morden Surrey).

'Wampole Laboratories, Stanford, Connecticut, USA (English address, Denver Laboratories, 12 Carlisle Road, London, N.W.9).

'Burroughs Wellcome \& Co., Euston, London, N.W.1.

Received for publication 16 May 1968. diagnosis tests: Pregnosticon ${ }^{2}$ (a haemoagglutination inhibition tube test); and three-complement fixation slide tests, Hyland HCG-test, ${ }^{5}$ Pregslide, ${ }^{3}$ and Gravindex. ${ }^{1}$ In addition, 238 of these urines were tested with Planotest, ${ }^{2}$ another complement-fixation slide test. Two hundred further urines were tested with Planotest alone.

The sensitivities of the tests were:

Gravindex, 3,000 to 3,500 iu/l. (stated on the product). Pregnosticon, 1,000 iu/l. (stated on the product).

Planotest, 2,500 iu/l. (manufacturer's personal communication).

Pregslide, 3,000 iu/l. (manufacturer's personal communication).

Hyland, 2,000 to 6,000 iu/l. (manufacturer's personal communication).

It was noted during the preparation of this paper that the pattern of results with the Hyland HCG test had changed during the course of the work, the earlier results showing fewer false positives and more false negatives than the later results. Baxter laboratories were contacted and informed us that they had changed the sensitivity of their test from $6,000 \mathrm{iu} / \mathrm{l}$. through 4,500 iu/l. to 2 to 3,000 iu/l., which they are currently supplying. We were unable to obtain the exact dates when these changes were made and are thus unable to include all the results with the Hyland slide test in this paper. Few tests were carried out with the Hyland test at a sensitivity of $6,000 \mathrm{iu} / \mathrm{l}$. and these have been excluded. The results obtained using the Hyland test at a sensitivity of $4,500 \mathrm{iu} / \mathrm{l}$. are referred to as type $A$ and with a sensitivity of 2 to $3,000 \mathrm{iu} / 1$. as

${ }^{5}$ Hyland Laboratories, Los Angeles, California, USA (English address, Baxter Laboratories Ltd, Thetford, Norfolk). 
type B. The importance of pregnancy diagnosis kits carrying an approximate estimate of their sensitivity cannot be overemphasized and users should be notified if a change is made. Without this, mistakes and confusion can arise when interpreting results.

All urines were filtered before testing and the urines were tested for protein by the salicyl sulphonic acid test and Albustix, ${ }^{6}$ blood by Haemostix ${ }^{6}$ and for salicylates with ferric chloride. No urine was tested earlier than 35 days after the stated date of the last menstrual period. All urines not tested immediately were refrigerated and all glassware used in the tests was thoroughly washed in tap water followed by distilled water. Soap and detergents were not used.

SLIDE TESTS The tests were carried out according to the manufacturers' instructions. It was found easier to read the result in daylight but when artificial light was used it was found best to use a Tungsten bench lamp, the slide being held near, but not directly under, the light. The results were read as positive (no agglutination), negative (agglutination present), and inconclusive (doubtful agglutination).

TUBE TEST The test was carried out according to the manufacturers' instructions. The result was read as positive (definitive, well formed brown ring), negative (no ring formation), and inconclusive (a very open, thin or irregularly formed ring). The end point of the tube test was easy to read and tests could be carried out either in daylight or artificial light.

\section{RESULTS}

UNCOMPLICATED PREGNANCIES Table I shows the results in 203 uncomplicated pregnancies. Pregnosticon was the most sensitive test used, giving only one false negative $(0.5 \%)$. The patient giving the false negative result was tested at 37 days after the date of the last menstrual period, and gave a positive result with Pregnosticon and Gravindex, an inconclusive result with Pregslide and a negative

Ames Co., Inc., Elkhart, Indiana, USA (English address, Division of Miles Laboratories Ltd, Stoke Poges, Slough, Bucks.). result with Hyland $A$ when tested 21 days later. Planotest and Gravindex had a similar sensitivity,Planotest giving $2.0 \%$ false negatives and Gravindex $\overline{\bar{A}}$ $3.5 \%$. Pregslide had $9 \%$ false negatives. Hyland Ao was the most insensitive test, giving $19.5 \%$, falseo negatives, Hyland $B$ gave $6.5 \%$ false negatives.

COMPLICATED PREGNANCIES AND PATHOLOGICAL CONDITIONS All pregnancy tests were positive in $\vec{\circ}$ the patient with a hydatidiform mole and negativein the follow up patients who were tested betweenc three and 18 months after the original diagnosis and treatment of the mole. The latter patients had no? evidence for recurrence of the mole.

Four patients were diagnosed clinically as ectopicpregnancies. With one of these patients no chorionic $v$ tissue was found histologically and the diagnosis is therefore in doubt. This patient had a negativepregnancy test by all five methods. One patient had a positive test with Pregnosticon and a negative? result with the other tests. This was presumably due to the greater sensitivity of Pregnosticon. One patient was positive with all tests and the other with all tests except Hyland A. Sixteen patients had $a^{c}$ threatened abortion. The patient with a negative result by all tests was tested at $\mathbf{4 0}$ days after the dates of the last menstrual period; this patient is still preg $-\bar{\partial}$ nant. Of the 11 patients with a positive result with each of the tests carried out, seven aborted within 16 to 33 days of the test, while four are still pregnant. The remaining four patients were positive with Pregnosticon and had varying results with the othertests. A single pregnancy test, therefore, appears to be of little help in the management of a threatened abortion.

The four patients with incomplete abortions alio had positive results, while patients with complete abortions generally gave negative results. Pregnosti-윽 con and Pregslide, however, gave inconclusive results

TABLE I

RESULTS OF PREGNANCY TESTS IN PREGNANT PATIENTS (EXCLUDING URINES CONTAINING BLOOD AND/OR PROTEIN)

Days after Last Menstrual Period

\begin{tabular}{l} 
\\
\hline $35-49$ \\
$50-59$ \\
$60-69$ \\
$70-79$ \\
$80-89$ \\
$90-99$ \\
$100-199$ \\
$>200$ \\
Longstanding amenorrhoea \\
No amenorrhoea \\
Postpartum amenorrhoea
\end{tabular}

Pregnosticon

+- \pm False In-

Negative conclusive
Hyland $A$

$\begin{array}{rr}42 & 1 \\ 52 & 0 \\ 45 & 0 \\ 18 & 0 \\ 13 & 0 \\ 7 & 0 \\ 13 & 0 \\ 3 & 0 \\ 2 & 0 \\ 1 & 0 \\ 2 & 0\end{array}$

$2 \cdot 2$

$2 \cdot 2$
0
0

o

0

o

o

o

0

0

o

$6 \cdot 5$
$1 \cdot 9$
0
0
0
0
0
0

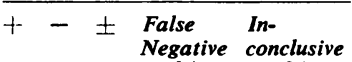

(\%) (\%)

\begin{tabular}{rrrrr} 
& & $(\%)$ & $(\%)$ \\
\hline 6 & 1 & 35 & 6 \\
& 2 & 1 & 12 & 6 \\
4 & 0 & 24 & 0 \\
& 1 & 0 & 17 & 0 \\
0 & 1 & 0 & 20 \\
0 & 0 & 0 & 0 \\
0 & 0 & 0 & 0 \\
0 & 0 & 0 & 0 \\
0 & 0 & 0 & 0 \\
0 & 0 & 0 & 0 \\
0 & 0 & 0 & 0
\end{tabular}
++ \pm False In- ON $+- \pm \begin{aligned} & \text { False In- } \\ & \text { Negative conclusive }\end{aligned}$ (\%) $(\%)$ б

(10

$\begin{array}{rrrcr}15 & 2 & 1 & 11 & 6 \\ 20 & 2 & 1 & 8 \cdot 7 & 4 \cdot 3 \\ 11 & 1 & 0 & 8 \cdot 3 & 0 \\ 4 & 0 & 0 & 0 & 0 \\ 5 & 0 & 0 & 0 & 0 \\ 5 & 0 & 0 & 0 & 0 \\ 8 & 0 & 0 & 0 & 0 \\ 2 & 0 & 0 & 0 & 0 \\ 1 & 0 & 0 & 0 & 0 \\ 0 & 0 & 0 & 0 & 0 \\ 1 & 0 & 0 & 0 & 0\end{array}$


with one patient each, two and three days respectively after the abortion.

NON-PREGNANT PATIENTS EXCLUDING URINES WITH PROTEIN AND BLOOD This group of patients was divided into menopausal and premenopausal because of the observation (Wide, Roos, and Gemzell, 1961; Lunenfeld, Isersky, and Shelesnyak, 1962; Hamashige and Arquilla, 1963; Taymor, Goss, and Buytendorp, 1963) that antisera to human chorionic gonadotrophin will crossreact with pituitary gonadotrophin. Patients with postpartum amenorrhoea were considered separately because of the observation (Bertini, 1965) that false positives are found in these patients. There were eight patients with postpartum amenorrhoea; all results were negative except one inconclusive with Pregnosticon.

Pregnosticon gave two inconclusive results in the menopausal group which became negative on diluting the urine. These were presumably due to the greater sensitivity of Pregnosticon causing pituitary gonadotrophins to be detected. In the premenopausal group, $0.5 \%$ false positives and $0.5 \%$ inconclusive were found with Planotest; $2 \cdot 1 \%$ false positives, $4 \cdot 1 \%$ inconclusive with Gravindex; $2 \cdot 6 \%$ false positives, $6.2 \%$ inconclusive with Pregnosticon; $4.7 \%$ false positives, $8 \%$ inconclusive with Pregslide; $3.6 \%$ false positives none inconclusive with Hyland A, and $8.7 \%$ false positives, $1.4 \%$ inconclusive with Hyland $\mathrm{B}$.

The 32 patients who gave false positive or inconclusive results with one or more of the pregnancy tests were thoroughly investigated to find if any cause for these false positives could be found. Three patients were taking steroids, two patients were on contraceptive pills, two on barbiturates, two on penicillin, and one each on chlordiazepoxide and Prochloroperazine and Nitrazepam. Eight patients had infertility, six menstrual irregularities, and two chronic active hepatitis. There were, however, 25 patients on barbiturates, seven patients on a contraceptive pill, four on chlordiazepoxide and three on penicillin, who did not give false positive results, so these compounds do not appear to be the cause of the false positives seen. No false positives were found in patients on salicylates.

NON-PREGNANT PATIENTS WITH URINE CONTAINING BACTERIA, PROTEIN, AND/OR BLOOD In this group of patients, Planotest was the only pregnancy test which did not give a false positive result. False positives with the other pregnancy tests appeared to be related more to protein in the urine than to bacteria but some urines with an $E$. coli infection gave a positive or inconclusive pregnancy test even in the absence of protein with Pregslide or Gravindex.

PREGNANCY TESTS ON BACTERIAL CULTURES Preparations of cultured staphylococci, streptococci, and of an E. coli-Proteus mixture were prepared with a bacterial count several times higher than that which would be present in a highly infected urine. These cultures were then tested undiluted and at a dilution of 1 in 10 and 1 in 20 . The only pregnancy test to give a positive was Hyland $B$ which reacted down to a 1 in 10 dilution with the staphylococci and gave an inconclusive result with undiluted streptococci.

EFFECT ON PREGNANCY TESTS OF ADDITION OF PROTEIN TO URINE Human albumin, ${ }^{7} \gamma$ globulin, ${ }^{7}$ and glycoprotein $^{8}$ were added to urines at varying 'A.B. Kabi, Stockholm, Sweden (English address, Bilton House Uxbridge Road, W.5).

${ }^{8}$ Koch-Light Laboratories Ltd, Colnbrook, Bucks.

TA BLE I-continued

RESULTS OF PREGNANCY TESTS IN PREGNANT PATIENTS (EXCLUDING URINES CONTAINING BLOOD AND/OR PROTEIN)

Days after Last Menstrual Period

\begin{tabular}{l} 
\\
\hline $35-49$ \\
$50-59$ \\
$60-69$ \\
$70-79$ \\
8089 \\
$90-99$ \\
$100-199$ \\
$>200$ \\
Longstanding amenorrhoea \\
No amenorrhoea \\
Postpartum amenorrhoea \\
\\
Overall results \\
No. tested \\
False negative (\%) \\
Inconclusive (\%)
\end{tabular}

Gravindex

$+\quad \pm \begin{array}{ll}\text { False } & \text { In- } \\ \text { Negative } & \text { conclusive }\end{array}$

(\%) $(\%)$

Planotest

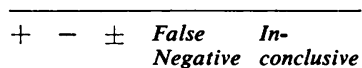
(\%) (\%) 
concentrations to investigate the relative nonspecificities of the pregnancy tests. Using human albumin at a concentration of $2 \mathrm{~g} / 100 \mathrm{ml}$ urine, positive results were obtained with Hyland B, Pregslide, and Gravindex but not with Pregnosticon or Planotest. At a concentration of $1 \mathrm{~g} / 100 \mathrm{ml}$ negative results were found with all tests. Using human $\gamma$ globulin, Planotest and Pregnosticon gave inconclusive results at concentrations of 2 and $1 \mathrm{~g}$ $\gamma$ globulin/100 ml. Pregslide and Gravindex gave positive results down to $250 \mathrm{mg} / 100 \mathrm{ml}$ and Gravindex gave a further two inconclusive results at 125 and $62.5 \mathrm{mg} / 100 \mathrm{ml}$. Hyland $B$ gave positive results at concentrations down to $125 \mathrm{mg} / 100 \mathrm{ml}$. Human glycoprotein (Cohn fraction VI) gave positive results only with Gravindex and Hyland B. Gravindex and Hyland B gave positive results down to $500 \mathrm{mg} / 100 \mathrm{ml}$. Gravindex also gave an inconclusive result at $250 \mathrm{mg} / 100 \mathrm{ml}$.

TESTS ON FILTERED AND UNFILTERED URINE Although all tests in this series were on filtered urine, a series of tests was carried out with the slide methods to find if filtering was absolutely necessary. Six urines with varying degrees of cloudiness were tested. The only difference found was with one moderately cloudy urine, which gave a positive result with Pregslide on the filtered urine and an inconclusive result on the unfiltered urine. It would appear from this small series that filtration may not be necessary before pregnancy testing with Planotest, Hyland, Pregslide, or Gravindex.

\section{DISCUSSION}

To be completely satisfactory a pregnancy test should give neither false positive nor false negative results.

In this survey Planotest was the most satisfactory method for eliminating false positives, giving only $0.5 \%$ false positives in protein and blood-free urine from non-pregnant patients compared with $2 \cdot 1 \%$ for Gravindex, 2.6\% with Pregnosticon, $4.7 \%$ with Pregslide, $3.6 \%$ with Hyland A, and $8.7 \%$ with Hyland B. False positive immunological tests could be due to a number of different reasons: technical factors (Noto and Miale, 1964), impurity of reagents (Lunenfeld et al, 1962; Loewitt, 1966), cross reaction of the antihuman chorionic gonadotrophin (antiHCG) preparation with antigens other than HCG (Wide et al, 1961; Wide and Gemzell, 1962; Goss and Lewis, 1964), and other as yet undetermined causes. Tests using albumin, $\gamma$ globulin, glycoprotein, and various bacteria have shown that Pregnosticon and Planotest contain the purest reagents, only giving inconclusive results with
$1 \mathrm{~g} \gamma$ globulin/100 ml. Since a fairly high proportio of pregnant females may have non-symptomatic bacteriuria and/or proteinuria, a pregnancy te which does not give false positives under these circumstances is wanted (Godts and Mighores, 1964; Kew, Seftel, and Bloomberg, 1967), otherwise it is necessary to maintain a biological test. Tha lower limit of sensitivity of immunological pregnancy tests needs to be set at such a level that cross reactiof?s with pituitary gonadotrophins do not interfere Wide and Gemzell (1962) found that the level of luteinizing hormone in fertile and menopaus urine would be detected as 100 to 400 iu of HCE. and it has been suggested that the lower limit \&f sensitivity should therefore be set at 1,000 iu/lu, which is the limit for Pregnosticon. It would appear, however, from the two inconclusive results seen if the menopausal urine and the inconclusive resulfs seen in some patients with infertility that even at this level pituitary gonadotrophins may sometimess interfere.

A test which does not give a large number of false negatives is also required, especially in such caseg as ectopic pregnancies and threatened abortiones when the level of HCG may be much lower than that in normal pregnancy. In this series Pregnosticon wo the most suitable method, giving only $0.5 \%$ false negatives in normal pregnancies. Planotest had $2.0 \%$, Gravindex $3.5 \%$, Pregslide 9\%, Hyland $\frac{\mathrm{g}}{\mathrm{O}}$ $19.5 \%$, and Hyland B $6.5 \%$. False negative results using immunological pregnancy tests have bee reported in ectopic pregnancies (Southam, Sultze? and Cohen, 1963; Gusdon, 1964; Islami, Fisher, and Kupfer, 1964) and in threatened abortions (Hutche? son, Schwartz, and Bates, 1964; Sato and Greenblatti 1965; Fink and Frie, 1966). Pregnosticon gave the smallest number of false negatives in these condition in the present work.

The type of pregnancy test used will depend on the type of pregnancy being tested. As a genera्d pregnancy test, Planotest would appear to be the most efficient. In ectopic pregnancies and threatenes abortions it may be preferable to use a more sensitive test, such as Pregnosticon or a similar tuber test, but the number of false positives will then bes greater.

My thanks are due to the local general practitioners who were so helpful in supplying final diagnoses and othe्p relevant information on their patients, to the Obstetrics Department for access to their notes, and to Professor D. N. Baron for valuable help and criticism.

\section{REFERENCES}

Fink, H., and Frie, A. (1966). Obstet. and Gynec., 28, 66 Godts, P., and Mighorst, J. C. A. (1964). Amer. J. Obstet. Gyneç्Q $89,590$. 
Godd, D. A., and Lewis, J., Jr (1964). Endocrinology, 74, 83.

Gusdon, J. P., Jr (1964). Obstet. and Gynec., 23, 885.

Hamashige, S., and Arquilla, E. R. (1963). J. clin. Invest., 42, 546.

Hutcherson, W. P., Schwartz, H. A., and Bates, H. M. (1964). Amer. J. Obstet. Gynec., 89, 70.

Islami, Z., S., Fisher, L. M., and Kupfer, H. G. (1964). Ibid., 89, 586. Kew, M. C., Seftel, H. G., and Bloomberg, B. M. (1967). Lancet, 1, 902.

Loewit, K. (1966). Med. exp. (Basel), 14, 593.
Lunenfeld, B., Isersky, C., and Shelesnyak, M. C. (1962). J. clin. Endocr., 22, 555.

Noto, T. A., and Miale, J. B. (1964). Amer. J. clin. Path., 41, 273.

Sato, T., and Greenblatt, R. B. (1965). Amer. J. Obstet. Gynec., $91,31$. Southam, A. L., Sultzer, B. M., and Cohen, H. (1963). Amer. J. Obstet. Gynec., 85, 495.

Taymor, M. L., Goss, D. A., and Buytendorp, A. (1963). Fertil. and Steril., 14, 603.

Wide, L., and Gemzell, C. (1962). Acta endocr. (Kbh.), 39, 539.

-, Roos, P., and Gemzell, C. (1961). Ibid., 37, 445.

\section{The November 1968 Issue}

\section{THE NOVEMBER 1968 ISSUE CONTAINS THE FOLLOWING PAPERS}

Bone marrow in nine cases of clinical glandular fever and a review of the literature J. F. BOYD and D. REID

A sex difference in the leucocyte count R. N. ALLAN and M. K. ALEXANDER

Role of erythrocytes in the acute platelet response to operation P. N. BENNETT

Methodological study and a recommended technique for determining the euglobulin lysis time R. CHAKRABARTI, M. BIELAWIEC, J. F. EVANS, and G. R. FEARNLEY

Clotting factor $\mathrm{V}$ activity in plasma cryoproteins A. voN FELTEN, P. W. STRAUB, and P. G. FRICK

Semi-automatic method for routine evaluation of fibrinolytic components D. COLLEN, G. TYTGAT, and M. VERSTRAETE

Value of gel filtration on Sephadex G-200 in the analysis of blood group antibodies F. STRATTON, D. S. SMITH, and V. I. RAWLINSON

Plesiomonas shigelloides in South Australia R. G. COOPER and GERALDINE W. BROWN

Effect of dilution on the growth of bacteria from blood cultures A. P. C. H. ROOME and R. A. TOZER

Antibiotic resistance of coagulase-negative staphylococci and micrococci JEAN CORSE and R. E. O. WILLIAMS

Mycological tests and onychomycosis R. R. DAVIES

Advantage of a routine Reiter protein complementfixation test in the serodiagnosis of syphilis in pregnancy C. A. MORRIS

Structure and significance of metaplastic nodules in the rectal mucosa J. F. ARTHUR

Pathology of hereditary nephritis v. v. JOSHI

Staining method for the examination of the small intestinal villous pattern in necropsy material IAIN $\mathrm{W}$. DYMOCK and BRENDA GRAY
Mitral stenosis together with a giant cell myocarditis limited to the left atrium I. GILLIE and H. FOX

Porotic hyperostosis and the Gelligaer skull JOHN CULE and I. LYNN EVANS

Semi-automated method for the differential determination of plasma catecholamines HELEN MCCULLOUGH

A stable starch preparation for amylase determinations G. P. FRASER and J. C. B. FENTON

Assessment of thyroid status in pregnant women and in patients taking oral contraceptives by a free thyroxine index T. M. D. GIMLETTE and A. PIFfanelli

Residual formaldehyde after low-temperature steam and formaldehyde sterilization G. L. GIBSON, H. P. JOHNSTON, and V. E. TURKINGTON

\section{Technical methods}

Effect of unconjugated bilirubin on the estimation of serum iron by a modified Sanford technique PAUL M. SMITH, JOHN E. MIDDLETON, and ROGER WILLIAMS

Improved automated methods of protein determination D. F. GIBBS and C. M. J. BRIGHT

Micro modification of the dilute blood clot lysis time for determining fibrinolytic activity C. R. SPITTLE, N. M. LANSDOWN and C. M. HAWKEY

Erythrocyte mechanical fragility test R. G. COOPER, R. A. KAHN, C. N. CORNELL, and M. E. MUHRER

Differentiation of foetal and maternal erythrocytes in formol-fixed tissues C. G. PAINE

Mechanical rotary device for plating out bacteria on solid medium R. FRASER WILLIAMS and JENNIFER M. BAMBURY

Letter to the Editor

Book reviews

The Association of Clinical Pathologists: 81st general meeting

Index for 1968

Contents for 1968

Copies are still available and may be obtained from the PUBLISHING MANAGER, BRITISH MEDICAL ASSOCIATION, TAVISTOCK SQUARE, W.c.1, price $18 \mathrm{~s} .6 \mathrm{D}$. 